\title{
大腸菌における紫外線障害の光修復機構に関する研究
}

\section{A Study on the Mechanism of Photoreactivation in Escherichia coli}

\author{
国立栄養研究所 (The National Institute of Nutrition) \\ 山崎陽代 (Haruyo Yamazaki) 真田宏夫 (Hiroo Sanada) \\ 鈴江緑衣郎 (Ryokuero Suzue) 中 嶋 洋 子 (Yoko Nakashima) \\ 河田正 治 (Shoji Kawada)
}

Photoreactivation of ultraviolet (UV) damage has been demonstrated in many bacteria, plants and animals.

In the previous paper, we reported on the phenomenon of photoreactivation in vitamin $B_{1}$ requiring mutants of E. coli B. The present study was performed to clarify the mechanism of photoreactivation.

E. coli DNA labeled with ${ }^{3} \mathrm{H}$-thymidine was irradiated with UV light of $255 \mathrm{~m} \mu$. In the presence of visible light, the irradiated DNA was incubated with enzyme which was extracted from $E$. coli B. The reaction was terminated by addition of trichloroacetic acid. The precipitated DNA was hydrolyzed with formic acid, paper chromatographed and the radioactivity of each fraction was counted.

As the result of this experiment, a new radioactive peak of thymine dimer with $\mathrm{Rf}$ value 0.24 was observed.

However, about $30 \%$ of the dimers were split off from irradiated DNA by photoreactivating treatment.

It was concluded that photoreactivating enzyme exists in E. coli B, and UV-induced thymine dimers in DNA are eliminated by the enzyme in the presence of light.

著者らは前報に括いて, ビタミン $\mathrm{B}_{1}$ 要求大腸菌变異株に括ける紫外線障害の光修復作用について報告し, ビ タミン $\mathrm{B}_{1}$ 要求変異株の種類によって光修復能力に差があることや, 变異株は野生株に比べて光修復能力が低 いことなどを認めた1)。そこで今回は大腸菌に拈ける紫外線障害の光修復作用機構について研究した。

紫外線障害の原因の多くは，紫外線照射が細胞に影響を及涩して DNAに変化を起こすことであり，この細 胞内 DNAの変化の中で生物学的に特に重要なものはチミンダイマーの形成であることが報告されている2) そして紫外線障害の光修復機構は DNA 上に生じたチミンダイマーの monomerization と関係がめり, そこに 関与する酵素は光によって活性化されて DNA のチミンダイマーに作用するのであろうということが報告され ている(6) 。

この光修復酵素は, 酵母については Muhammed によって分離精製されており7), 紫外線照射したDNA を 酵母の光修復酵素とともに光を照射しながらインキュベートすることによって，チミンダイマーの monomerization が行なわれたことが報告されている899

このように酵母の光修復酵素に関する報告は多いが，大腸菌に関してはあまり報告されていない。そこで著 者らは前報で報告した大腸菌の光修復作用が，大腸菌に存在するであろう光修復酵素によるチミンダイマーの monomerization によるものであるかを調べ，紫外線障害の光修復機構について研究したので報告する。 


\section{実 験 材 料}

(1) 使用菌株

${ }^{3} \mathrm{H}-\mathrm{DNA}$ 抽出には, 金沢大学医学部久野教授より分与された E. coli W (3110-217) チミン要求菌を使用し, 光修復酵素源として E. coli B (ATCC 11303) を使用した。

(2) 使用培地

E. coli $\mathrm{W}$ Thy-の培養には前報と同様の最小培地 $10 \mathrm{~m} l$ にペプトン $2 \%$, チミン $40 \gamma,{ }^{3} \mathrm{H}$-標識チミシシン $100 \mu \mathrm{c}$ を加えた培地を使用した。 ${ }^{3} \mathrm{H}$-標識チミジン(methyl. ${ }^{3} \mathrm{H}$ ) は The Radiochemical Centre(Amersham England) より入手した。

E. coli B の培養には，最小培地にペプトン $1 \%$ ，酵母エキス0.5\%を加えた培地を使用した。

\section{実 験 方 法}

実験方法の概要は Fig. 1 に示した通りである。

Fig. 1. Experimental procedure

E. coli DNA ( ${ }^{3} \mathrm{H}$-thymine)

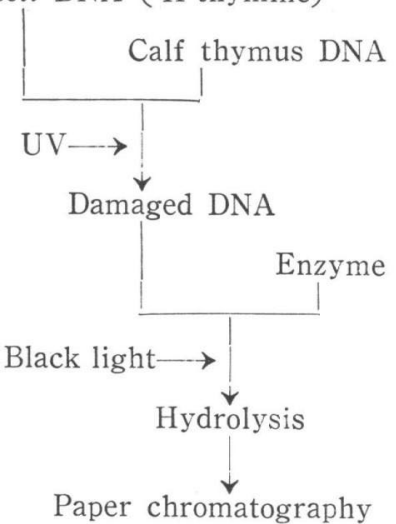

(1) ${ }^{3} \mathrm{H}$-標識 DNA の調製

実験材料の項で述べたように，E. coli W Thy-を ${ }^{3} \mathrm{H}$-チミジン (spec. act. $5.0 \mathrm{c} / \mathrm{mM}$ ) の含まれた培地 で対数末期まで培養し，菌体を集め，仔牛胸腺 DNA (type 1. Sigma Chem. Co.) 2mgを加光て, Marmur の方法 ${ }^{10)}$ とってDNAを抽出した。すなわち，菌体 を saline-EDTA（0.15 M-NaCl+0.1 M-EDTA）で 2 回遠心洗浄後 saline-EDTA に懸濁 L $25 \%$ sodium lauryl sulfate 莸加光 $60^{\circ} \mathrm{C}$ に10分間加熱後, 冷却し て溶菌させる。溶菌液に $5 \mathrm{M}$ の過塩素酸ソーダを $1 \mathrm{M}$ になるように加え, 等量のクロロホルム・イソアミル

アルコール $(24: 1 \mathrm{v} / \mathrm{v})$ を加えて30 分位振と弓し，3,000×g で遠心分離し，核酸成分を分離する。核酸溶 液に 2 倍量の泠エタノール（95\%）を静かに加兄, 粗 DNA をガラス棒に巻き取り, 希 saline-citrate 溶液 (0. 015M-NaCl+0. 015M-Na3-クエン酸) 飞溶解する。クロロホルム抽出, エタノール沈澱, 溶解の操作を くり返して精製し, 最後のエタノール沈搌物を希 saline-citrate に溶かし, 酿酸-EDTA (3.0M-酢酸ソー ダ+0.001M-EDTA）を1/10量加えて，激しく擋拌しながら0.54容のイソプロパノールを加えて DNA を選択 的に沈澱させ, 希 saline-citrate に溶かす。

(2) 酵素液の調褩

E. coli B ※ $1 l$ の培地で 1 晚培養し, 菌体（湿電量約 $1 \mathrm{~g}$ ）を $10,000 \times \mathrm{g}$ で10分間遠沈して集菌し, 緩衝 液（0.005M-グルタチオン，0.002M-EDTA，0.005M-リン酸緩衝液pH7.0，20\%ダリセロールを含む0.15M$\mathrm{KCl})^{11)} 10 \mathrm{~m} l$ を加えて $20 \mathrm{kc}$ の超音波発生装置で 5 分間破啸し，10,000× $\mathrm{g}$ で10分間遠沈して得られた上澄 を酵素液とした。酵素液の蛋白量は Warburg and Christian の方法により測定した ${ }^{22}$ 。

(3) 紫外線照射と光修復処理

${ }^{3} \mathrm{H}$-標識 DNA $\left(1.4 \times 10^{3} \mathrm{cpm} / \mu \mathrm{g}\right)$ に $15 \mathrm{~W}$ の紫外線灯を $5 \mathrm{~cm}$ の距離から氷で冷却しながら10分間照射した。 
照射 DNA $(50 \mu \mathrm{g})$ に酵素液 $0.5 \mathrm{~m} l$ (蛋白量 $14 \mathrm{mg} / \mathrm{ml}$ ), 緩衝液 $0.8 \mathrm{~m} l$ を加光, $320 \mathrm{~m} \mu \sim 420 \mathrm{~m} \mu$ の波長の 光線を照射しながら $37^{\circ} \mathrm{C} て ゙ 60$ 分間インキュベートした。

(4) 加水分解

光修復処理後， $20 \%$ トリクロル䣷酸（TCA） $1.5 \mathrm{~m} l$ 加兄て反応を止め, 沈澱物を $10 \%$ TCA $1 \mathrm{~m} l$ で洗い, エーテルで洗って TCA を除き沈澱物を $99 \%$ ギ酸で $175^{\circ} \mathrm{C}$ ，45分間加水分解した。

(5) ペーパークロマトグラフィー

加水分解物をワットマンの汇紙 (3MM) 飞つけ, n-ブタノール: 酰酸: 水 $=80: 12: 30$ の溶媒 ${ }^{13)}$ により, 室温で約20時間ペーパークロマトグラフィーを行なった。

(6) 放射能の測定

ペーパークロマトグラムを $1 \mathrm{~cm}$ 幅に切り, シンチレーター液 (Toluol $500 \mathrm{~m} l$, PPO $2 \mathrm{~g}$, POPOP50mg) に入れ，液体シンチレーションカウンターによって測定した。

\section{実験結果及び考察}

${ }^{3} \mathrm{H}$-標識DNA飞紫外線を照射し, 加水分解してペーパークロマトグラフィーを行ない, ${ }^{3} \mathrm{H}-$ チミンの放射活 性を測定した結果, Rf值 0.59 のチミンの位置の他に, Rf值 0.24 のチンダイマーの位置にピークが認められ た。紫外線を照射しない DNA にはチミンダイマーの位置にピークは認められなかった (Fig. 2)。このこと から紫外線照射によって DNA にチミンダイマーが形成されることは明らかである。

Fig. 2. Formation of thymine dimer by UVirradiation

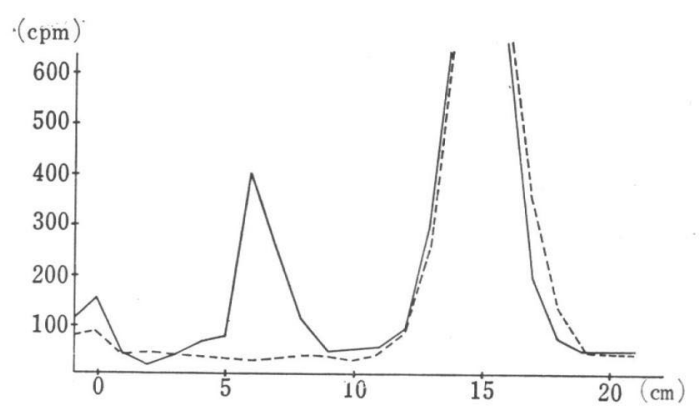

Table 1. Monomerization of thymine dimer

\begin{tabular}{|c|c|c|c|}
\hline $\begin{array}{c}\text { Incubation } \\
\text { time (min) }\end{array}$ & & $\frac{\text { dimer }}{\text { monomer }} \times 100(\%)$ & $\begin{array}{c}\text { ratio } \\
(\%)\end{array}$ \\
\hline 0 & & $11.4 \pm 0.4$ & 100 \\
\hline \multirow{2}{*}{60} & Dark & $11.6 \pm 0.5$ & 102 \\
\cline { 2 - 4 } & Light & $8.2 \pm 0.4$ & 73 \\
\hline
\end{tabular}

次に紫外線を照射した DNA を E. coli B から 抽出した酵素液とともに, $320 \mathrm{~m} \mu \sim 420 \mathrm{~m} \mu$ の光 線を照射しながら $37^{\circ} \mathrm{C}$ でインキュベートした結 果, 紫外線照射によって形成されたチミンダイマ 一の約 30\%が monomerize された。320m $420 \mathrm{~m} \mu$ 光線を照射せずに暗所でインキュベート した場合には, チミンダイマーの monomerization は認められなかった(Tab.1)。

これらの結果は大腸菌にチミンダイマーのmonomerization に関与する酵素が存在することを 示し，その䤉素は $320 \mathrm{~m} \mu \sim 420 \mathrm{~m} \mu$ の光線照射によ って活性化されるのであろうと考えられる。

Setlow らは酵母の光修復酵素によってチミン ダイマーの約 $80 \%$ が除去されたということを報告 しているが14), 今回著者らが行なった実験では, 大腸菌の酵素によってダイマーは約 $30 \%$ しか除去 されなかった。このことから酵母と大腸菌の紫外線に対する著しい感受性の違いは, チミンダイマーの除去修 復に関与する酵素の活性の違いと関係があるのではないかと考えられる。また大腸菌においてチミンダイマー の除去修復欠損株 $\left(\mathrm{e} \times \mathrm{c}^{-}\right)$でも著しい修復を示したという報告もあり $\left.{ }^{15}\right)$, 大腸菌にはダイマーの除去が行な われなくても修復を導く能力があることも考觉られる。 
しかしながら，紫外線照射によってDNA にチミンダイマーが形成され，障害の原因となっていることは明 らかであり，紫外線障害の修復過程には，必然的ではないにしろ，チミンダイマーの除去が重要な部分を占め ていることは明らかである。

\section{要約}

紫外線障害の光修復機構について, 特にチミンダイマーの monomerization について研究した。その結果, ${ }^{3} \mathrm{H}$-チミジン標識 DNA に紫外線を照射することによって DNA にチミンダイマーが形成されることは明らか となりこのチミンダイマーを含む DNA を大腸菌より抽出した酵素液とともに $320 \mathrm{~m} \mu \sim 420 \mathrm{~m} \mu$ の光線を照 射しながら $37^{\circ} \mathrm{C} て ゙ 60$ 分間インキュベートすることによってダイマーの monomerization は約 $30 \%$ 認められた。

本研究は三島海雲記念財団の学術研究奖励金の御援助を受けた。ここに深甚な謝意を表します。また E. coli $\mathrm{W}$ チミン要求菌を分与下さった金沢大学医学部第 2 生化学教室久野㴊教授に深く感謝する。

\section{文献}

1）山崎陽代，鈴江緑衣郎，真田宏夫，中嶋洋子，河田正治：栄養学雑誌，28，53 (1970)

2) R. Beukers and W. Berends: Biochim. Biophys. Acta., 41, 550 (1960)

3) A. Wacker, H. Dellweg and D. Weinblum: J. Mol. Biol., 3, 787 (1961)

4) R. B. Setlow, W. L. Carrier and F. J. Bollum: Proc. Nat. Acad. Sci. (U.S.), 53, 1111 (1965)

5) H. Harm and C. S. Rupert: Mutation Res., 6, 355 (1968)

6) W. Harm, H. Harm and C. S. Rupert: Mutation Res., 6, 371 (1968)

7) A. Muhammed: J. Biol. Chem., 241, 516 (1966)

8) R. B. Setlow and W. L. Carrier: J. Mol. Biol., 17, 237 (1966)

9) J. S. Cook: Photochem. Photobiol., 6, 97 (1967)

10) J. Marmur: J. Mol. Biol., 3, 208 (1961)

11) J. S. Cook and J. R. Mcgrath: Proc. Nat. Acad. Sci. (U. S.), 58, 1359 (1967)

12) O. Warburg and W. Christian: Biochem. Z., 310, 384 (1941)

13) C. Smith: Photochem. Photobiol., 2, 503 (1963)

14) R. B. Setlow and W. L. Carrier: J. Mol. Biol., 17, 237 (1966)

15）鈴木掔之, 森明充興, 島津良枝, 堀井善一郎, 斉藤恵津子： シンポジウム「放射線障害の回復」報文 集 3, 放射線医学総合研究所, (1968) 